\title{
Land Drainage and Flood Defence Responsibilities
}

\section{Fifth edition}


Downloaded by [] on [26/04/23]. Copyright @ ICE Publishing, all rights reserved. 
Land Drainage and Flood Defence Responsibilities

Fifth edition

Institution of Civil Engineers 
Published by ICE Publishing, One Great George Street, Westminster, London SW1P 3AA

Full details of ICE Publishing sales representatives and distributors can be found at: www.icebookshop.com/bookshop_contact.asp

\section{Other titles by ICE Publishing:}

Floods and Reservoir Safety, Fourth edition. Institution of Civil Engineers. ISBN 978-0-7277-6006-7

A Guide to the Reservoirs Act 1975, Second edition.

Institution of Civil Engineers. ISBN 978-0-7277-5769-2

Flood Risk.

P. Sayers (ed.). ISBN 978-0-7277-6063-0

www.icebookshop.com

A catalogue record for this book is available from the British Library.

ISBN 978-0-7277-6063-0

(c) Thomas Telford Limited 2016

ICE Publishing is a division of Thomas Telford Ltd, a wholly-owned subsidiary of the Institution of Civil Engineers (ICE).

All rights, including translation, reserved. Except as permitted by the Copyright, Designs and Patents Act 1988, no part of this publication may be reproduced, stored in a retrieval system or transmitted in any form or by any means, electronic, mechanical, photocopying or otherwise, without the prior written permission of the publisher, ICE Publishing, One Great George Street, Westminster, London SW1P 3AA.

This book is published on the understanding that the author is solely responsible for the statements made and opinions expressed in it and that its publication does not necessarily imply that such statements and/or opinions are or reflect the views or opinions of the publishers. While every effort has been made to ensure that the statements made and the opinions expressed in this publication provide a safe and accurate guide, no liability or responsibility can be accepted in this respect by the author or publishers.

While every reasonable effort has been undertaken by the author and the publishers to acknowledge copyright on material reproduced, if there has been an oversight please contact the publishers and we will endeavour to correct this upon a reprint.

Commissioning Editor: Laura Balchin

Development Editor: Maria Inês Pinheiro

Production Editor: Rebecca Norris

Market Development Executive: Elizabeth Hobson

Typeset by Academic + Technical, Bristol

Index created by Laurence Errington

Printed and bound in Great Britain by Bell + Bain Ltd, Glasgow 


\section{Contents}

Acknowledgements

Preface

Abbreviations and definitions

01

Outline of responsibilities and statutes

Scope of land drainage

General principles

Statutory functions

Principal statutes

02

Devolved government and departments

England

Wales

Scotland

Northern Ireland

03

Environment Agency

Supervisory duty

Surveying duty

Principal powers - main rivers and ordinary watercourses

Designation of main rivers

Powers to ensure maintenance of flow in watercourses

Powers to require repairs to watercourses, bridges and other infrastructure

Incidental powers

Directions to IDBs

Power to carry out schemes for small areas

Power to make byelaws

Flood warning systems

Tidal flooding and coastal erosion

Financing of land drainage functions

General aims and environmental duties

04

\section{Internal drainage boards}

Functions and constitution

Land Drainage Act 1991

Water Resources Act 1991

Financial arrangements for IDBs

Drainage rates and special levies

Differential rates

Higher land water contribution (HLWC) from the Environment Agency to the IDB

Additional funding

Environment Agency precept (from IDB to Environment Agency) 
05

Local authorities

Outline of powers - England and Wales 35

English district councils 36

English and Welsh county councils and unitary authorities

The London authorities

Scottish local authorities

Northern Ireland local authorities

06

\section{Riparian owners}

Riparian rights and duties $\quad 47$

Nuisance 51

Obstruction to flow - consent procedure 52

Disputes regarding ditches 52

Disputes between neighbours 52

Powers of entry 52

Problems regarding grant aid 52

Flooding emergencies 53

Artificial watercourses $\quad 53$

Obstruction and flooding $\quad 54$

$07 \ldots \ldots \ldots \ldots \ldots \ldots \ldots \ldots$ Differentiation between land drainage and sewerage

Difference between a public sewer and a watercourse 55

Guidelines for differentiation $\quad 57$

Definition of a public sewer 57

Tests to check the status of a public sewer 61

Transfer of Private Sewers Regulations $2011 \quad 61$

Supplementary transfer scheme 62

$08 \ldots \ldots \ldots \ldots \ldots \ldots \ldots$ Development either side of a watercourse

09

Extension of the 'main river' designation of watercourses

10

Development planning and management

Introduction $\quad 73$

England $\quad 73$

Wales $\quad 73$

Scotland $\quad 73$

Northern Ireland $\quad 74$

Planning procedures $\quad 74$

Consideration of land drainage matters $\quad 78$

Conditions for consent $\quad 78$

Planning obligations $\quad 80$

Requirement for information and advice $\quad 80$ 
Requirements for works, agreements etc.

11

Development in flood plains

National Planning Policy Framework

Risk-based approach

Sequential test

Exception test

Responsibilities for developments in a flood plain $\quad 88$

Planning policy - Northern Ireland

12

\section{Roadside ditches}

Ownership problems

Filling in or culverting

Powers of diversion

Culverts under highways

Acceptance of other flows

Drainage to existing sewers

Runoff onto highways

Right of statutory undertakers to discharge into a ditch or watercourse

Ditches maintained by the highway authority

13

\section{Culverted watercourses}

Summary of problems

Control over culverting

Practical problems associated with culverting

Legal problems associated with culverting

14

\section{Grants and contributions}

Policy framework

Environment Agency funding

Lead local flood authority expenditure

Internal drainage boards

Legislation

Administration

Useful publications

Contributions

Devolved governments

15

Mining subsidence and land drainage

Principal statutes

Coal Mining Subsidence Act 1991

Mining codes

Pollution of watercourses 
Introduction

Environmental obligations

Environmental impact assessment

18

Bibliography

Websites

Books, updated loose-leaf volumes, reports and articles

Appendix 1

Relevant statutes, Statutory Instruments, EC legislation and current Government policy guidance to which reference is made

Appendix 2

List of cases to which reference is made

Index 
The Institution of Civil Engineers (ICE) is indebted to Roland Grzybek, David Porter and Brian Rodgers, members of the ICE Water Expert Panel, who have updated and rewritten large parts of this text for the fifth edition of Land Drainage and Flood Defence Responsibilities.

Roland Grzybek has worked in the flood and coastal risk management sector for over 40 years and is currently the Flood and Coastal Risk Management Director for $\mathrm{CH} 2 \mathrm{M}$. His experience is in the feasibility, design and construction of flood alleviation schemes in the UK and selected countries in Europe. He is a Fellow of the ICE and the Chartered Institution of Water and Environmental Management (CIWEM). He is also Chair of the Thames Estuary Partnership, Chair of the ICE London Executive Board and ICE London Regional Committee, and sits on the ICE Water Expert Panel. He has been an ICE reviewer for over 25 years.

David Porter is currently the Chief Executive of the Department for Infrastructure's Rivers Agency, the flood defence and drainage authority for Northern Ireland. The Agency is responsible for river and sea defence maintenance, the construction of flood alleviation schemes and the provision of flood maps and risk information, and it carries out the role of Lead Government Department for flood emergency events throughout Northern Ireland. Previously, David has been the Director of Development and the Director of Operations at the Rivers Agency, and has also worked for the Roads Service. David is a chartered civil engineer and is a Fellow of the ICE. He is the immediate past Chair and the ICE Council representative for the Northern Ireland Region.

Brian Rodgers has recently retired from Wycombe District Council, where he was Lead Officer for Flooding and Emergency Planning Officer. Prior to that he gained extensive practical experience in designing, constructing and maintaining land drainage and flood defence schemes for Mersey and Weaver River Authority, British Waterways and the Environment Agency. He has been a member of the ICE Water Expert Panel for 9 years and has represented the ICE on a number of committees, including the Local Authority FRM Capacity Building Programme and Environment Agency Research and Development Programme Board. He has taken the lead on responding to several government consultations on flood issues on behalf of the ICE. 
Downloaded by [] on [26/04/23]. Copyright @ ICE Publishing, all rights reserved. 
The fourth edition of this guide was published in 2009, at a time when the responsibility for managing flood risk was under scrutiny following major floods in Carlisle, Hull and the River Severn valley.

In August 2007, the Government, in response to the concerns, asked Sir Michael Pitt to lead an independent review into the floods that occurred in June and July of 2007. His final report was published in June 2008 and it contained 92 recommendations, which the Government agreed to implement in full.

Following a period of consultation, the majority of the recommendations were incorporated in the Flood and Water Management Act 2010, enacted on 8 April 2010. This Act made a number of significant changes to the responsibility for managing flood risk, including the introduction of the concept of lead local flood authorities (LLFAs) and risk management authoritis (RMAs), a role given to upper-tier local authorities in England and Wales. In Wales, the reorganisation of the Environment Agency, the Countryside Commission for Wales and the Forestry Commission for Wales into Natural Resources Wales has changed flood risk responsibility.

In addition to the changes in England and Wales, the devolved administration in Scotland has also made changes to the way flood risk is managed. These changes were incorporated in the Flood Risk Management (Scotland) Act 2009, with the key responsibilities for flood risk management implemented by the Scottish Environment Protection Agency (SEPA). In Northern Ireland, the Department for Infrastructure is responsible for flood risk management.

The change in responsibility for organisations in all four countries of the UK, and the emphasis in legislation on flood risk management, which deals with all sources of flooding, together with greater autonomy in the devolved administrations, have led to the requirement for this new edition of this book.

\author{
Brian Rodgers \\ ICE Water Expert Panel
}


Downloaded by [] on [26/04/23]. Copyright @ ICE Publishing, all rights reserved. 


\title{
Abbreviations and definitions
}

\author{
Abbreviations \\ ADA \\ Association of Drainage Authorities \\ CA \\ Coal Authority \\ CIA 1994 \\ Coal Industry Act 1994 \\ CIRIA \\ Construction Industry Research and Information \\ Association \\ CMP \\ Catchment Management Planning \\ CMSA 1991 \\ Coal Mining Subsidence Act 1991 \\ COW \\ Critical ordinary watercourse \\ CPA 1949 \\ DCLG \\ Coast Protection Act 1949 \\ Department for Communities and Local Government \\ Defra \\ Department for Environment, Food and Rural Affairs \\ DETR \\ Department of the Environment, Transport and the \\ Regions \\ DfI \\ Department for Infrastructure (Northern Ireland) \\ DO 1973 \\ Drainage (Northern Ireland) Order 1973 \\ DoE \\ Department of the Environment \\ EA \\ Environmental assessment \\ EA 1995 \\ Environment Act 1995 \\ EC \\ European Community \\ EIA \\ Environmental impact assessment \\ ES \\ FCERM \\ FCERM-AG \\ FD \\ FRM(Scot) \\ FRMP \\ FWMA10 \\ GDPO 1995 \\ GDPO 2015 \\ Environmental statement \\ Flood and coastal erosion risk management \\ Flood and Coastal Erosion Risk Management Appraisal \\ Guidance \\ Floods Directive 2007/60/EC \\ Flood Risk Management (Scotland) Act 2009 \\ Flood Risk Management Plan \\ Flood and Water Management Act 2010 \\ Town and Country Planning (General Development \\ Procedure) Order 1995 \\ Town and Country Planning (General Permitted \\ Development) (England) Order 2015 \\ HA 1980 \\ Highways Act 1980 \\ HLWC \\ Higher land water contributions \\ IDB \\ Internal drainage boards
}




\begin{tabular}{|c|c|}
\hline LDA 1991 & Land Drainage Act 1991 \\
\hline LDA 1994 & Land Drainage Act 1994 \\
\hline LDD & Local development documents \\
\hline LFDC & Local flood defence committee \\
\hline LGA 1992 & Local Government Act 1992 \\
\hline LG(W)A 1994 & Local Government (Wales) Act 1994 \\
\hline LPA & Local planning authority \\
\hline LLFA & Lead local flood authority \\
\hline NAW & National Assembly for Wales \\
\hline NIEA & Northern Ireland Environment Agency \\
\hline NPPF & National Planning Policy Framework \\
\hline NRA & National Rivers Authority \\
\hline NRW & Natural Resources Wales \\
\hline PCPA 2004 & Planning and Compulsory Purchase Act 2004 \\
\hline PFRA & Preliminary flood risk assessment \\
\hline PHA 1875 & Public Health Act 1875 \\
\hline PHA 1936 & Public Health Act 1936 \\
\hline PPS15 & Planning Policy Statement 15: Planning and Flood Risk \\
\hline PPS25 & Planning Policy Statement 25: Development and Flood Risk \\
\hline PSCA & Public Sector Cooperation Agreement \\
\hline RFCC & Regional flood and coastal committee \\
\hline RFRA & Regional flood risk appraisal \\
\hline RMA & Risk management authority (FWMA10) \\
\hline $\mathrm{S}$. & Section number of an Act of Parliament \\
\hline SEA & Strategic environmental assessment \\
\hline SEPA & Scottish Environment Protection Agency \\
\hline SFRA & Strategic flood risk assessment \\
\hline SI & Statutory Instrument \\
\hline SMP & Shoreline management plan \\
\hline SMP2 & Second-generation shoreline management plan \\
\hline SS. & Section numbers of an Act of Parliament \\
\hline SSSI & Site of special scientific interest \\
\hline SuDS & Sustainable drainage system \\
\hline SWMP & Surface water management plan \\
\hline TCPA 1990 & Town and Country Planning Act 1990 \\
\hline WA 1989 & Water Act 1989 \\
\hline
\end{tabular}


WA 2014

WAG

WCA 1981

WIA 1991

WRA 1991

WSS 2006
Water Act 2014

Welsh Assembly Government

Wildlife and Countryside Act 1981

Water Industry Act 1991

Water Resources Act 1991

Water and Sewerage Service (Northern Ireland) Order 2006

\section{Statutory definitions}

Designated watercourse: Means a watercourse in Northern Ireland that has been designated by the Drainage Council. (DO 1973)

Drainage: Includes defence against water (including sea water), irrigation other than spray irrigation, warping and the carrying on, for any purpose, of any other practice which involves management of the level of the water in a watercourse (S.72(1) LDA 1991 and S.113(1) WRA 1991 as amended by S.100 EA 1995). References in the LDA 1991 to the carrying out of drainage works include references to the improvement of drainage works. (S.72(5) LDA 1991)

Drainage authority: Means the Department of Agriculture and Rural Development in Northern Ireland. (DO 1973 para. (6))

Drainage body: Means the Environment Agency, an internal drainage board or any other body having the power to make or maintain works for the drainage of land. (S.72(1) LDA 1991)

\section{Flood:}

(1) Includes any case where land not normally covered by water becomes covered by water.

(2) It does not matter for the purpose of subsection (1) whether a flood is caused by-
(a) heavy rainfall,
(b) a river overflowing or its banks being breached,
(c) a dam overflowing or being breached,
(d) tidal waters,
(e) groundwater
(f) surface water
(g) pluvial and sewerage
(e) anything else (including any combination of factors).

(3) But 'flood' does not include-

(a) a flood from any part of a sewerage system, unless wholly or partly caused by an increase in the volume of rainwater (including snow and other precipitation) entering or otherwise affecting the system, or

(b) a flood caused by a burst water main (within the meaning given by S.219 of the WIA 1991). (S.1 FWMA10)

Flood defence: Means the drainage of land and the provision of flood warning systems.

(S.I13(1) WRA 1991) 
Flood risk management function: Means a function listed in subsection (2) which may be exercised by a risk management authority for a purpose connected with flood risk management.

(2) The functions are-

(a) a function under this Part,

(b) a function under section 159 or 160 of the Water Resources Act 1991,

(c) a flood defence function within the meaning of section 221 of that Act,

(d) a function under the Land Drainage Act 1991,

(e) a function under section 100, 101, 110 or 339 of the Highways Act 1980, and

(f) any other function, under an enactment, specified for the purposes of this section by order made by the Minister.

(3) In this section and section 5 'the Minister' means-

(a) the Secretary of State in relation to flood and coastal erosion risk management in England, and

(b) the Welsh Ministers in relation to flood and coastal erosion risk management in Wales. (S.4 FWMA10)

Flood warning system: Means any system whereby, for the purpose of providing warning of any danger of flooding, information with respect to specified matters is obtained and transmitted, whether automatically or otherwise, with or without provision for carrying out calculations based on such information and for transmitting the results of those calculations. The specified information is with respect to: (a) rainfall, as measured at a particular place within a particular period; (b) the level or flow of any inland water, or any part of an inland water, at a particular time; and (c) other matters appearing to the Environment Agency to be relevant to providing warning of any danger of flooding. (S.148(5) WRA 1991)

Lead local flood authority: Means the unitary authority or county council for that area within England and Wales.

Local authority: Means the council of a county, county borough, district or London borough, or the Common Council of the City of London (S.72(1) LDA 1991 and S.221(1) WRA 1991)

Main river: Means a watercourse shown as such on a main river map (S.193/4 WRA 1991), and includes any structure or appliance for controlling or regulating the flow of water into, in or out of, the channel which is: (a) a structure or appliance situated in the channel or in any part of the banks of the channel; and (b) not a structure or appliance vested in or controlled by an internal drainage board (S.I13(1) WRA 1991, and see S.137(4) WRA 1991 as amended by S.59 WA 2014).

Ordinary watercourse: Means a watercourse that does not form part of a main river (S.72(1) LDA 1991, and see the definition of 'main river' above).

Public sewer: Means a sewer for the time being vested in a sewerage undertaker in its capacity as such, whether vested in that undertaker by virtue of a scheme under Schedule 2 to the WA 1989, S.179 of Schedule 2 to the WIA 1991 or otherwise (S.221(1) WRA 1991, and S.219(1) WIA 1991). (WSS 2006) 
Sewer: Includes all sewers and drains that are used for the drainage of buildings and yards appurtenant to buildings, excluding a drain used for the drainage of one building or of buildings or yards appurtenant to buildings within the same curtilage (S.219(1) WIA 1991 and S.221(1) WRA 1991) (WSS 2006). References to a 'sewer' are to include references to a tunnel or conduit which serves similarly or to any accessories thereof (S.219(2) WIA 1991 and S.221(2) WRA 1991).

Watercourse: Includes all rivers and streams and all ditches, drains, cuts, culverts, dikes, sluices, sewers (other than public sewers within the meaning of the WIA 1991) and passages through which water flows (see S.72(1) LDA 1991, and above on the meaning of 'public sewer'; similarly, see S.I13(1) WRA 1991, but contrast with S.221(1) WRA 1991). See also DO 1973. 